\title{
Biodiversity loss in a small riverine wetland of the Ticino river (Lombardia, Northern Italy)
}

\author{
Daniele PAGANELLI, ${ }^{*}$ Renato SCONFIETTI \\ Department of Earth and Environmental Sciences, University of Pavia, via S. Epifanio 14, 27100 Pavia, Italy \\ *Corresponding author: daniele.paganelli@unipv.it
}

\begin{abstract}
Wetlands are heterogeneous habitats that include various biotopes with different formations, structures and geographical positions. There are many small wetlands in the Ticino river area around Pavia (Lombardia, Northern Italy), many of which evolve naturally and originate from abandoned riverbeds, isolated river meanders, oxbow lakes or small ponds fed by terrace springs or underground waters. We decided to consider the evolution of one of these wetlands, namely the Topo oxbow lake. It had previously been studied 24 years ago (1988-1990), so we compared the results with those collected during a recent one-year investigation (June 2011-June 2012) on the following aspects: dimensions, hydrometric level fluctuation and bathymetry, principal chemical-physical parameters, hygrophytic and aquatic vegetation, and zooplankton communities. The resulting geo-morphological and biotic community changes are typical of riverine wetlands, thus supporting the hypothesis that this oxbow lake is following its natural evolution. Morphological changes in the oxbow lake should influence its biotic communities: the high plant biomass that existed in the past could be considered to have been the first step towards eutrophication, but the oxbow lake remained at mesotrophic level due to high biodiversity and dissolved oxygen levels in the water. Nowadays, the lower biodiversity in aquatic plants and zooplankton suggests a trophic level shift towards eutrophication due to the endogenous evolution of the oxbow lake. However, these ideas are not supported by the physical and chemical parameters of the water which indicate that the oxbow lake is still at mesotrophic level. We would suggest planning a gentle restoration of this biotope, with the aim of rejuvenating the physical habitat to ensure the long-term ecological functioning of the aquatic environment.
\end{abstract}

Key words: wetlands, oxbow lake, zooplankton, aquatic plants.

Received: February 2013. Accepted: June 2013.

\section{INTRODUCTION}

The Ramsar Convention defines wetlands as areas of marsh, fen, peatland or water, whether natural or artificial, permanent or temporary, with water that is static or flowing, fresh, brackish or salt, including areas of marine water the depth of which at low tide does not exceed $6 \mathrm{~m}$ (Ramsar, 1971). However, the term wetlands has been defined and interpreted in various ways.

Wetlands are considered to be heterogeneous habitats which include various biotopes with different formations, structures and geographical positions (Sconfietti and Paganelli, 2012). In particular, small wetlands are referred to as stepping stone habitats because of their important role as a habitat haven for many animal and plant species, some of which are threatened or protected (habitat directive 2000/60/EC) (European Community, 2000). Natural riverine wetlands usually contain dense hygrophytic and aquatic vegetation, which is important for the ecosystem depuration processes (Sacchi et al., 1991). Abandonment and isolation of these lateral fluvial basins has occasionally led to environmental deterioration: anthropogenic pressure such as excavation and agricultural activities, construction of new bridges, streets and waste landfills have often isolated these natural areas from the rest of the environment (Schmitz, 2012). In the Ticino river area around Pavia (Lombardia, Northern Italy) there are a lot of small wetlands, many of which evolve naturally and originate from abandoned riverbeds, isolated river meanders, oxbow lakes or small ponds fed by terrace springs or underground waters. Some of such biotopes, located in the proximity of Pavia, are not only important from a landscape and ecological point of view, but they also have historical and social relevance for citizens (Sacchi et al., 1993). In 2010, these factors led to the creation of a project with the main aim of improving the chemical, bio-ecological and hydrologic conditions of the wetlands near Pavia. The project Ecological and hydromorphological requalification of wetlands in the Ticino area around Pavia was co-financed by the Cariplo Foundation, Municipality of Pavia, Park of Lombardia in the Ticino valley, Interregional Agency for the Po river (AIPO), and the University of Pavia.

Studies had previously been performed on one of these wetlands, the Topo (TO) oxbow lake, between 1988 and 1990 (Sconfietti et al., 1990, 1992; Sconfietti and Airò, 1992; Sconfietti, 1993; Cantonati and Sconfietti, 1996). The TO oxbow lake originated in 1750 due to an artificial rectification of the main course of the Ticino river, which 
caused a meander cut. In 1930, its area was reduced in order to construct a new gate on the Ticino river (Sacchi et al., 1993). Nowadays, the oxbow lake is a shallow basin situated on the right of the Ticino river from which it is completely isolated, except on the rare occasion when there is particularly severe flooding (Fig. 1). Due to its isolation from the river, the water level fluctuates very slowly but it is still influenced by the river level. Although the surrounding area is characterised by intensive agricultural activities, and is separated from the basin by a high river embankment and a few buildings, such as a country club and tennis courts, the anthropogenic pressure is very low: the absence of sewage or a direct link between the basin and the fields around it, are evidence of a low impacted ecosystem.

In order to compare the status of the TO oxbow lake 24 years ago with its current ecological and hydrological status, we investigated its dynamics over the course of one year, from June 2011 to June 2012. We compared the dimensions, bathymetry, hydrometric variation of the basin and the aquatic vegetation from 24 years ago with current data and, in order to define the current trophic level of the oxbow lake, we also measured the principal chemical- physical parameters of the water. Furthermore, we followed the natural dynamics of the zooplankton community in the oxbow lake.

\section{METHODS}

In order to define the geo-morphological evolution of the TO oxbow lake, in April 2012 at the minimum level of water, we measured the dimensions and the bathymetry of the basin with a laser rangefinder Leica DISTO A5 (Leica DISTO, Nocera Inferiore, Italy) and a hydrometric pole. We also followed the hydrometric variation of the oxbow lake by using a $5 \mathrm{~cm}$ graduate pole, which we positioned in the northern part of the basin for the duration of the year-long survey.

We recorded the principal chemical-physical parameters of the water once a month: temperature, transparency, $\mathrm{pH}$, dissolved oxygen, nitrate $\left(\mathrm{N}-\mathrm{NO}_{3}\right)$, nitrite $\left(\mathrm{N}-\mathrm{NO}_{2}\right)$, ammonia $\left(\mathrm{N}-\mathrm{NH}_{4}\right)$, total nitrogen (tot $\mathrm{N}$ ) and total phosphorus (tot $\mathrm{P})$, biochemical oxygen demand $\left(\mathrm{BOD}_{5}\right)$ and chemical oxygen demand (COD). We analysed the principal chemical data by means of Merck's spectroquant chemical kit and a photometer NOVA 60 (Millipore, Billerica, MA, USA). In order to compare the current status

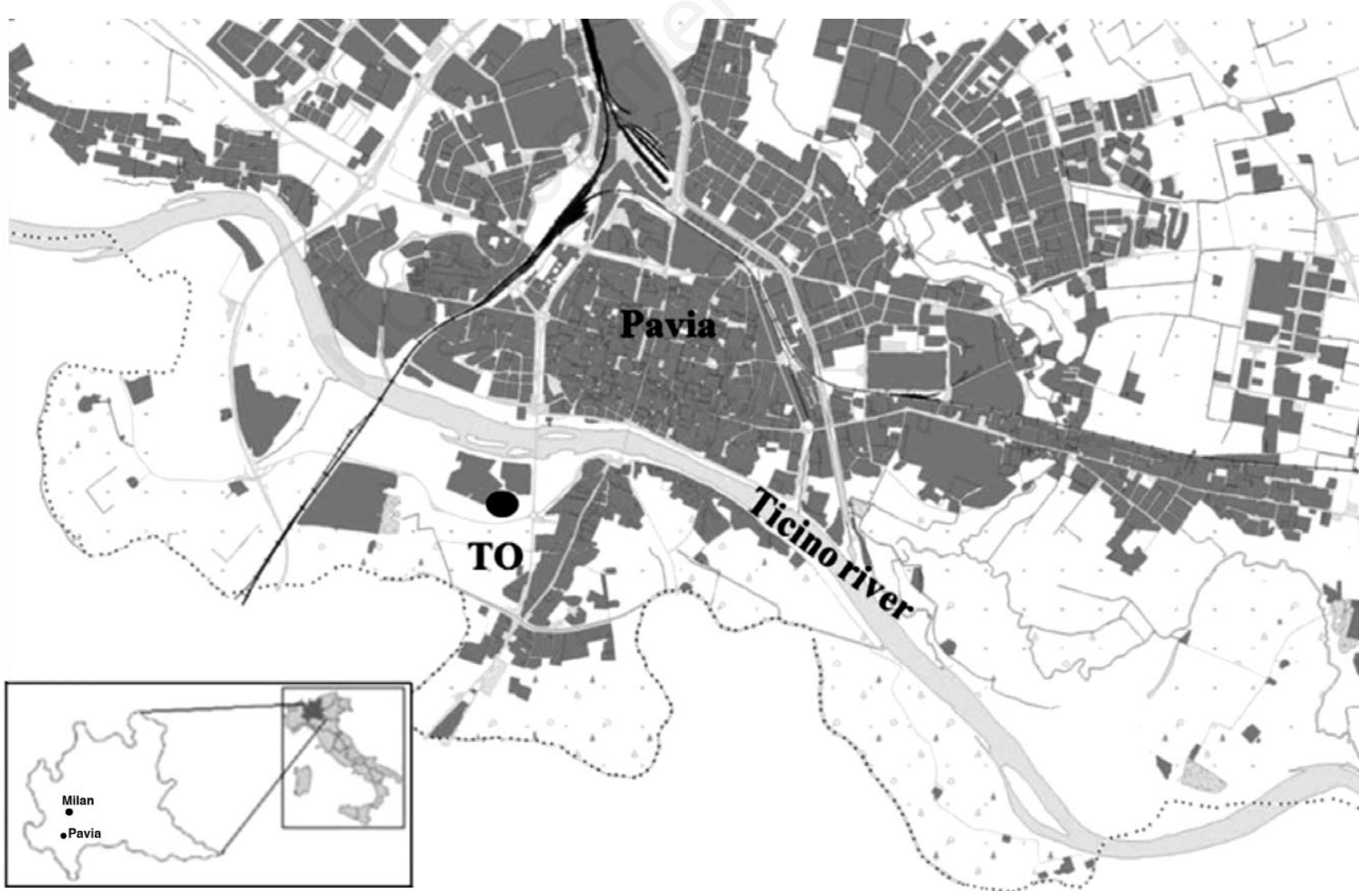

Fig. 1. Study area. TO, Topo oxbow lake. 
of the oxbow lake with the status described 24 years ago, we repeated the same protocol zooplankton survey proposed by Cantonati and Sconfietti (1996): we used a modified plankton net which was built specifically for sampling in shallow waters by Sconfietti and Cantonati (1990). The floating plankton net was towed for $5 \mathrm{~m}$, thus collecting $625 \mathrm{~L}$ of filtered water; samples were then fixed and identified in the laboratory. For each sample we collected four replicates for the subsequent statistical analyses. In order to describe the zooplankton community, data were analysed by means of univariate analysis such as number of species and Shannon index diversity, which integrates the species richness and their abundance in a given community (Shannon and Weaver, 1949). Moreover, with the aim of highlighting seasonal difference in the zooplankton community, samples were analysed through a multidimensional scaling (MDS) analysis, a multivariate technique that reveals the structure of the data set by plotting points in two dimensions; an ANOSIM test was performed in order to confirm the statistical significance. A SIMPER analysis was then applied in order to define the most dominant species for each season. All the statistical analyses were carried out using the software PRIMER 5.0 (Clarke and Warwick, 1994).

Furthermore, due to the small size of the biotope, we carried out a visual census of the entire wetland area, identifying and marking the distribution of the vegetation in the oxbow lake and monitoring its natural dynamics.

\section{RESULTS}

\section{The Topo oxbow lake 24 years ago}

If we consider the usual boundaries of the water's edge nowadays, we can see that the oxbow lake had a different shape in the past: it was more elongated, especially in the south-western part where there was a shallow area (Fig. 2). In total, the oxbow lake was $167 \mathrm{~m}$ long and 67 $\mathrm{m}$ wide, with a maximum depth of $230 \mathrm{~cm}$ and an estimated water area of $3900 \mathrm{~m}^{2}$ (Cantonati and Sconfietti, 1996). The hydrometric level of the oxbow lake was closely linked to the variation of the water level of the Ticino river: the highest level was recorded in June 1989, corresponding to the spring rains. The bottom consisted of sand and gravel and was covered by a layer of organic matter. In 1988-1990, a total of 21 species of aquatic or hygrophyte plants were recorded (Tab. 1). The north-eastern edge of the basin was occupied by two dominant species of reeds: Phragmites australis and Schoenoplectus lacustris. In addition, there were a few specimens of Sparganium erectum and Scirpus sylvaticus. The most abundant aquatic species was Myriophyllum spicatum, which reduced the presence of other submerged plants, in particular Potamogeton spp. and Najas minor. On the other hand, floating leaf plants such as Nymphaea alba and
Nymphoides peltata and the submerged Lagarosiphon major and Ceratophillum demersum were not influenced by the abundance of $M$. spicatum; $N$. peltata was mainly distributed in the south-western part of the oxbow lake. Furthermore, in June 1990, the first specimen of Nuphar lutea was recorded.

The chemical parameters recorded described the typical seasonal dynamics of small wetlands: a slight dystrophic crisis was recorded in the summer of 1988 and in November 1988. Except for these two occasions, the percentage

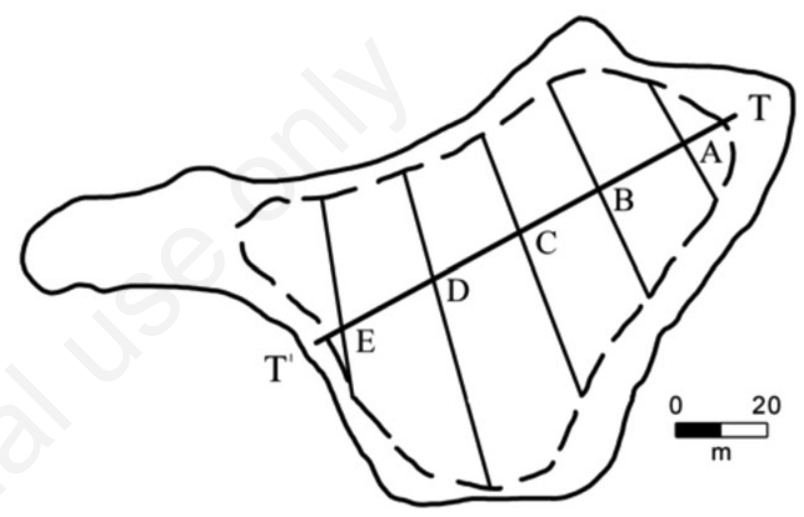

Fig. 2. The shape of the Topo oxbow lake in 1989 (straight line) and 2012 (dashed line). T-T', longitudinal transect; A-E, transversal transects.

Tab. 1. List of hygrophitic and aquatic plants collected in 19881990 and in 2011-2012.

\begin{tabular}{|c|c|c|}
\hline & $1988-1990$ & 2011-2012 \\
\hline Agrostis stolonifera L. & + & - \\
\hline Ceratophyllum demersum $\mathrm{L}$. & + & - \\
\hline Chara spp. & - & + \\
\hline Glyceria spp. & - & + \\
\hline Lagarosyphon major (Ridley) & + & - \\
\hline Lythrum salicaria L. & + & - \\
\hline Myriophillum spicatum L. & + & - \\
\hline Najas flexilis (Willd.) Rostk. \& Schmidt & + & - \\
\hline Nymphaea alba L. & + & - \\
\hline Nymphoides peltata Kuntze & + & + \\
\hline Nuphar lutea L. & + & + \\
\hline Phragmites australis & + & + \\
\hline Polygonum mite (Schrank) Assenov & + & - \\
\hline Potamogeton crispus L. & + & - \\
\hline P. lucens L. & + & - \\
\hline P. natans L. & + & - \\
\hline P. pectinatus $\mathrm{L}$. & + & - \\
\hline P. perfoliatus L. & + & - \\
\hline Rorippa amphibia $\mathrm{L}$ & + & - \\
\hline Schoenoplectus lacustris L. & + & - \\
\hline Scirpus sylvaticus L. & + & - \\
\hline Sparganium erectum L. & + & - \\
\hline Utricularia australis L. & + & + \\
\hline
\end{tabular}

+ , detected; -, not detected. 
of oxygen saturation was always above $100 \%$. $\mathrm{pH}$ values varied from neutral to weakly alkaline, in accordance with the dissolved oxygen variation. A dystrophic crisis had led to a high concentration of orto-phosphorus in these two periods; however, in general it was always under $0.5 \mathrm{mg} \mathrm{L}^{-1}$. The concentration of nitrogen compounds was always very low: nitrites varied between 0.07 and $0.017 \mathrm{mg} \mathrm{L}^{-1}$, nitrates varied between 0.153 and $0.036 \mathrm{mg} \mathrm{L}^{-1}$ and ammonia varied between 0.902 and $0 \mathrm{mg} \mathrm{L}^{-1}$. The zooplankton community was composed of 13 species of Cladocerans, 3 Copepods, 12 Rotifers and 5 Protista (Tab. 2). The mean

Tab. 2. List of the zooplankton species found in 1988-1990 and in 2011-2012.

\begin{tabular}{|c|c|c|}
\hline & 1988-1990 & 2011-2012 \\
\hline \multicolumn{3}{|l|}{ Cladocerans } \\
\hline Acroperus harpae (Baird) & + & - \\
\hline Alonella excisa Brehm & + & - \\
\hline Alona guttata Sars & + & - \\
\hline Biapertura affinis Leydig & + & - \\
\hline Bosmina longirostris Müller & + & + \\
\hline Chydorus sphaericus Mueller & + & - \\
\hline Ceriodaphnia laticaudata Müller & + & - \\
\hline Daphnia longispina Müller & + & - \\
\hline D. obtusa Müller & - & + \\
\hline Diaphanosoma brachyurum Liévin & + & - \\
\hline Macronthrix hirsuticornis Norman and Brady & + & - \\
\hline Moina micrura (Kurz) & + & + \\
\hline Pleuroxous aduncus Baird & + & + \\
\hline P. truncatus Müller & + & - \\
\hline \multicolumn{3}{|l|}{ Copepods } \\
\hline Diaptomus spp. & + & - \\
\hline Mesocyclops edax Forbes & + & - \\
\hline M. leuckartii Claus & + & - \\
\hline Thermocyclops dybowskii Landè & - & + \\
\hline \multicolumn{3}{|l|}{ Rotifers } \\
\hline Asplanchna priodonta Gosse & + & + \\
\hline Brachionus angularis Gosse & + & + \\
\hline B. calyciflorus Pallas & - & + \\
\hline B. quadridentatus Hermanns & - & + \\
\hline B. falcatus Zacharias & + & + \\
\hline B. patulus (Müller) & + & + \\
\hline Filinia longiseta (Ehrenberg) & + & + \\
\hline Keratella quadrata (Müller) & + & + \\
\hline K. cochlearis (Gosse) & + & + \\
\hline K. tropica (Apstein) & + & - \\
\hline Lecane luna (Müller) & + & - \\
\hline L. quadridentata (Ehrenberg) & + & + \\
\hline Platyas quadricornis Harring & - & + \\
\hline Polyarthra euriptera Wierzejski & + & + \\
\hline Trichocerca cylindrical Sudzuki & + & - \\
\hline \multicolumn{3}{|l|}{ Protista } \\
\hline Centropyxis aculeata (Ehrenberg) & + & - \\
\hline Difflugia acuminate Ehrenberg & + & - \\
\hline D. corona Wallich & + & - \\
\hline D. lobostoma Leidy & + & - \\
\hline D. oblonga Ehrenberg & + & - \\
\hline Acanthocystis chaetophora Carter & - & + \\
\hline
\end{tabular}

+ , detected; -, not detected. density recorded was 100,000 ind $\mathrm{m}^{-3}$ but, on a few occasions, the density of zooplankton reached 400,000 ind $\mathrm{m}^{-3}$. The Shannon diversity index (H') ranged from 0.2 to 2.5 and the number of species (S) ranged from 4 to 12 . All the chemical and biological data details are listed in Sconfietti et al. (1990) and Cantonati and Sconfietti (1996).

\section{Current status of the Topo oxbow lake}

The water surface area of the oxbow lake $\left(2812 \mathrm{~m}^{2}\right)$ is smaller than it was in the past: it has an oval shape, 50 $\mathrm{m}$ wide and $90 \mathrm{~m}$ long (Fig. 2); the maximum width of the basin $(53 \mathrm{~m})$ is at the centre, which is also its deepest part $(160 \mathrm{~cm})$. The mean hydrometric level of the oxbow lake was $58.43 \pm 23.44 \mathrm{~cm}$ with a minimum level recorded in April 2012 and a maximum recorded in November 2011 (Fig. 3). Although the bottom of the basin is covered by a thick layer of organic matter, it is actually made of gravel; this is evidence of its riverine origin. Shallow depth and good water transparency is an ideal habitat for aquatic vegetation: in total there are 6 species of aquatic or hygrophytic plants (Tab. 1). The north-eastern edge of the basin is occupied by the marshy plant species Phragmites australis, the center of the basin is dominated by the floating leaf plant Nuphar lutea, and the rest of the oxbow lake is colonised by green algae Chara spp. The rest of the aquatic vegetation comprises a few specimens of Glyceria spp., Nymphoides peltata (mainly in the eastern part of the basin), and a few floating plants of Utricularia australis. The photosynthesis processes of aquatic plants influence $\mathrm{pH}$ values, which vary in the oxbow lake between 7.8 and 6.6, and the water is almost always super saturated (dissolved oxygen $=101.5 \pm 48 \%$ ). High abundance of plants also influences the level of nitrogen compounds, which are very low in the oxbow lake: $\mathrm{N}_{-} \mathrm{NH}_{4}$ varies between 0.06 and $0.007 \mathrm{mg} \mathrm{L}^{-1}, \mathrm{~N}-\mathrm{NO}_{2}$ concentra-

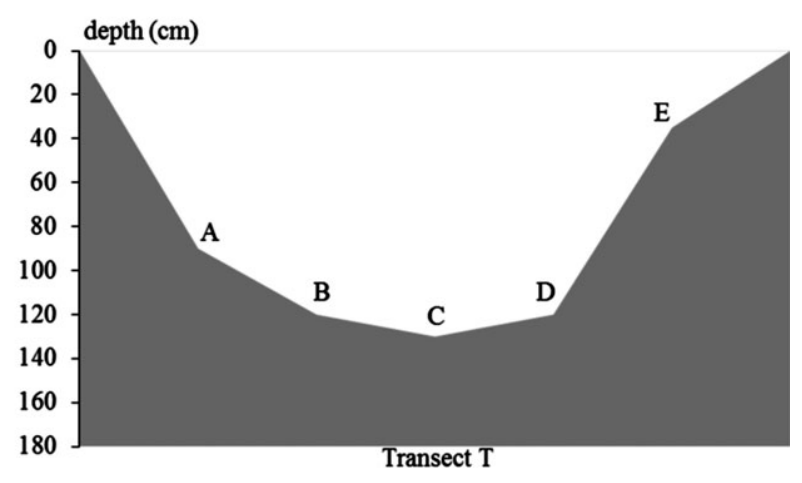

Fig. 3. Bathymetry profile of Topo oxbow lake recorded at the minimum hydrometric level (April 2012). A-E, transversal transects (see also Fig. 2). 
tion ranges from 0.08 to $0.006 \mathrm{mg} \mathrm{L}^{-1}$ and $\mathrm{N}-\mathrm{NO}_{3}$ concentration is always under the sensibility of the photometer. Total nitrogen is relatively high due to the organic matter decomposition, ranging from 2 to $0.4 \mathrm{mg} \mathrm{L}^{-1}$. The southeastern part of the basin, where we sampled zooplankton, is the deepest area of the oxbow lake and there is no aquatic vegetation.

The zooplankton community contains 18 species: 4 Cladocerans, 1 Copepod, 12 Rotifers and 1 Protista (Tab. 2). A univariate analysis of the zooplankton community shows a mean density of $770.09 \pm 830.6$ ind $\mathrm{m}^{-3}$, a mean number of species of 7.7 \pm 2.05 (Fig. 4) and a mean Shannon diversity of $2.07 \pm 0.37$ (Fig. 5); all of these structural community parameters show a slightly seasonal trend. Multidimen- sional scaling analysis suggests a seasonal difference among samples (Fig. 6) and an ANOSIM test confirms this hypothesis (R: 0.63, $\mathrm{P}=0.001$ ). SIMPER analysis reveals that the zooplankton community in summer is dominated by Copepodites nauplii ( $24 \%$ of the total) and the Rotifer Asplachna priodonta (21\% of the total); in autumn the most abundant taxa are Copepodites nauplii (30.7\% of the total) followed by the Cladoceran Pleoroxous aduncus $(20 \%$ of the total); winter is characterised by a high abundance of the Rotifer Keratella quadrata (23\% of the total) and the Cladoceran Bosmina longirostris (22.6\% of the total); spring is dominated by $B$. longirostris ( $24.1 \%$ of the total) and $A$. priodonta ( $20.3 \%$ of the total). The seasonal variations of the most abundant species are presented in Fig. 7.
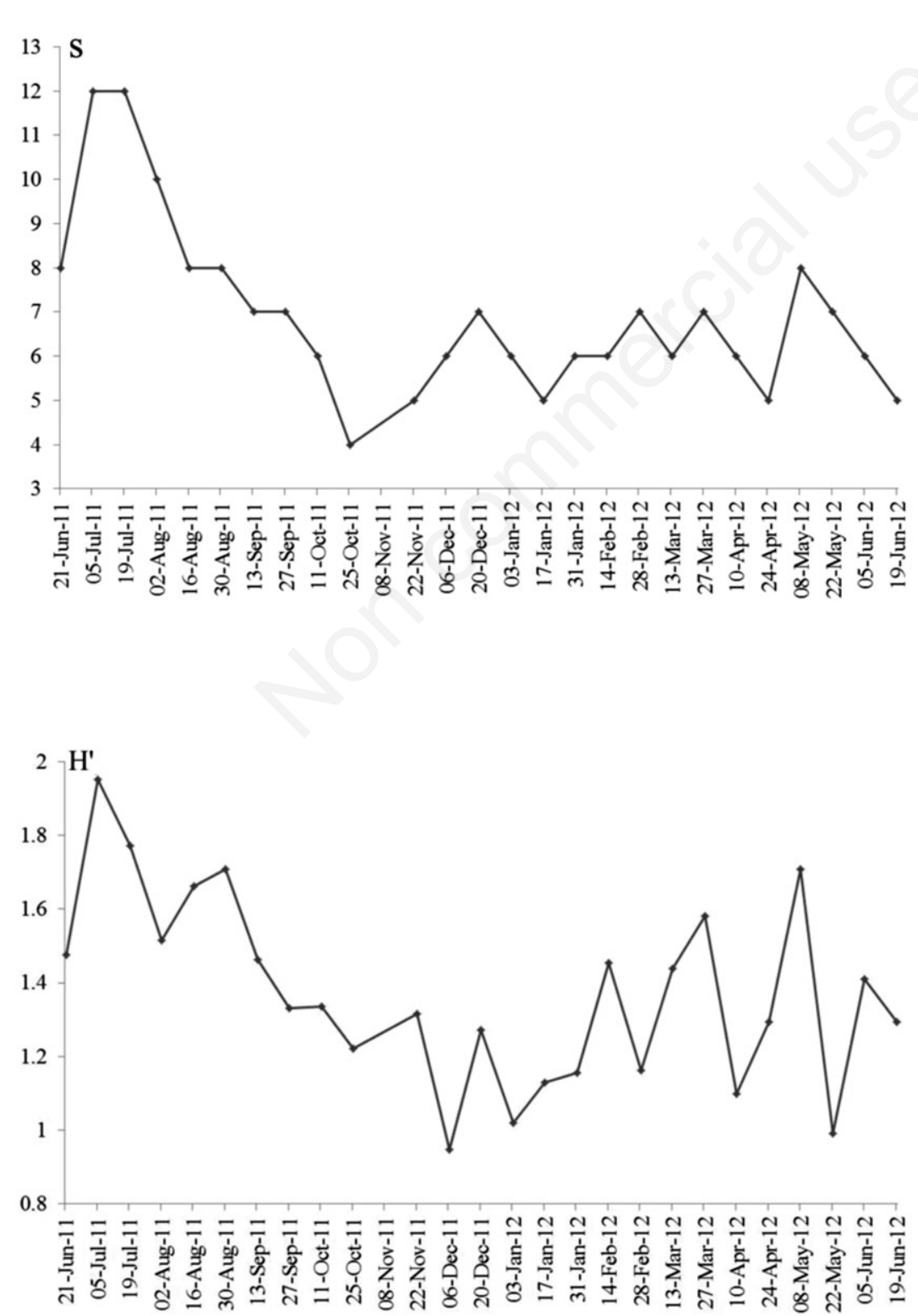

Fig. 4. Seasonal trend of number of species (S).

Fig. 5. Seasonal trend of Shannon diversity index ( $\left.\mathrm{H}^{\prime}\right)$. 


\section{DISCUSSION}

The morphology of the oxbow lake has changed over time: 24 years ago it was longer and deeper than it is today. The reduction of the area of the basin is only partially due to impoundment; it is more directly linked to a progressive decrease of the hydrometric level of the main course of the Ticino river, which is a consequence of its erosion activity. These morphological changes that describe the natural evolution of an oxbow lake could influence the biotic communities which inhabit the ecosystem such as fish, zooplankton and plants.

Ellenberg (1974) classified vascular plants of the German flora according to six ecological factors: light, temperature range, geographical distribution, humidity, soil $\mathrm{pH}$ and concentration of nutrients. In 1980, Pignatti classified the Italian flora using the same method and, according to his classification, it is possible to use Italian flora as a bio-indicator. The most abundant aquatic plant 24 years ago was the submerged Myriophillum spicatum, which prefers to live in shadow water or in full light, but only for short periods. It is typical of temperate areas, it tolerates large temperature variations and usually inhabits soil which is neutral-basophile and rich in nutrients (Pignatti, 1980). Other submerged plants, such as Nymphaea alba, Nymphoides peltata and Lagarosiphon major inhabit temperate areas in shallow full-light biotopes (from 30 to $110 \mathrm{~cm}$ deep), characterised by low water currents and neutral-basophile in rich nutrient soil (Pignatti, 1980).

Nowadays, the vascular flora of the oxbow lake contains drastically fewer species than it did in the past. Many species have totally disappeared: Schoenoplectus lacustris, Potamogeton spp., Ceratophillum demersum and Myrio- phillum spicatum. Nymphaea alba, whose distribution has drastically reduced in Lombardia (Regione Lombardia, 2010), has been completely substituted by Nuphar (N.) lutea, which appeared for the first time in the TO oxbow lake in 1990 and proceded to become the dominant aquatic plant in this wetland. $N$. lutea is a floating leaf plant with a broad ecological range with respect to water alkalinity, tolerating well-buffered and even acidic water bodies (Hutchinson, 1975; Smits et al. 1988; Shimoda, 1993). It is also well-adapted to anoxic sediments (Grosse, 1996) and is usually found at a depth ranging from $50 \mathrm{~cm}$ to $2 \mathrm{~m}$ (Laing, 1941). N. lutea has low sensitivity to physicalchemical water characteristics, which is probably due to the fact that its colonization is linked to the availability of very thick muddy substrata rather than to a specific trophic level (Gomarasca et al., 2010). The tolerance and capability of $N$. lutea to form dense networks between specimens could be an advantage in the competition with other plants which colonise the lentic waters of the Po river plain.

Another dominant component of the current aquatic vegetation, which was absent in the past, is the algae of the genera Chara. These algae are typical of shallow low current fresh water bodies with a silty/clay or sand substrate (Corillion, 1975; Carbiener et al., 1990). Characee are considered to be indicators of oligotrophic or mesotrophic biotopes with low nutrients and high alkalinity (Blindow, 1992, 1994): biotopes with these green algae are quite rare in the Po river plain (Habitat Directive 92/43/EC) (European Community, 1992). Aquatic plants provide a good haven for zooplankters against fish predators (Moss et al., 1998).

A comparison of the zooplankton community in 1989-1990 and 2011-2012 revealed a general decrease

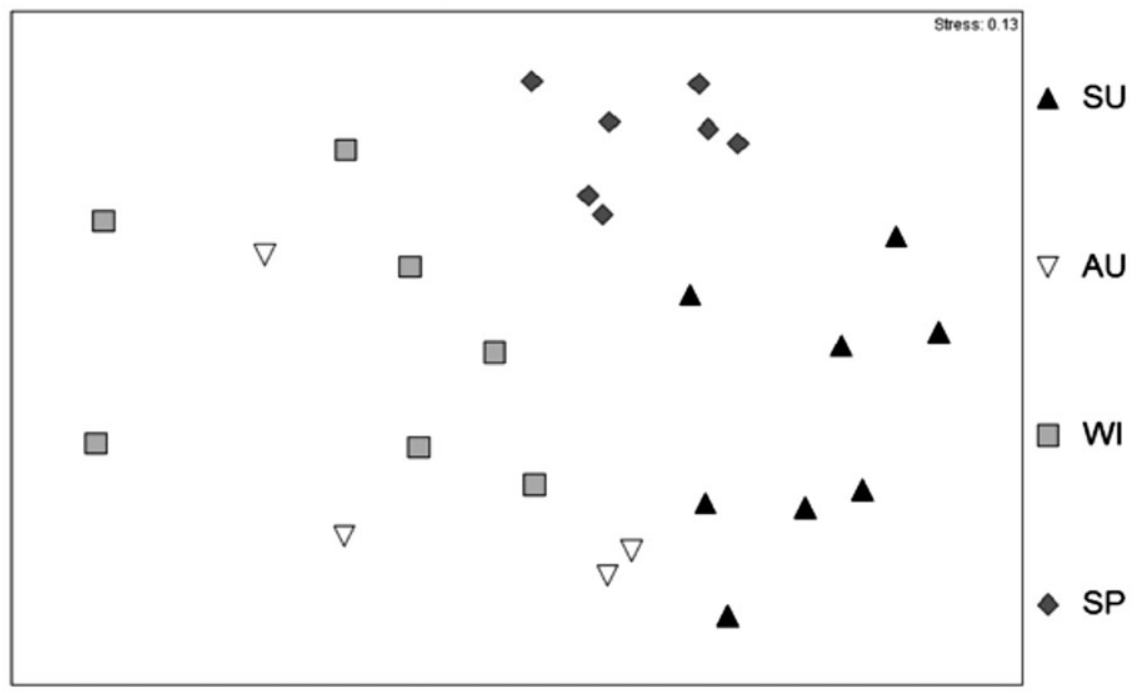

Fig. 6. Seasonal multidimensional scaling plot of the zooplankton community. SU, summer; AU, autumn; WI, winter; SP, spring. 
in species number: from 29 to 18 (Tab. 2). In particular, the number of species of Cladocerans dramatically decreased: from 14 in 1989-1990 to 4 in 2011-2012. The number of Rotifers remained almost unchanged, while the number of Copepod species decreased from 3 to 1 . The density of zooplankters also drastically changed: during 1988-1990, the density reached very high numbers $\left(400,000\right.$ ind $\left.\mathrm{m}^{-3}\right)$, whereas 24 years later, it never exceeded 3400 ind $\mathrm{m}^{-3}$. Rotifer is the most abundant group of the community. This could be explained by the following reasons: they have a high reproduction rate, they are more tolerant than several Cladocerans, and they can also survive with a lower concentration of food (Stemberger and Gilbert, 1985).

Another important factor could be their body size: in a biotope with a high density of fish, such as the TO oxbow lake, Rotifers are too small to be selected by most visually feeding fish which tend to prey on large Cladocerans and Copepods (Gilbert, 1985). In a pond in Central Italy, Margaritora et al. (2001) obtained similar results: high abundance of small zooplankters, such as Rotifers, was related to the presence of the mosquitofish Gambusia affinis and its selective predation of the large-bodied species. In their study, the elimination of this fish led to an increase in large-bodied species and a decrease in the density of smaller organisms.

Furthermore, Rotifers are generally superceded by large Cladocerans (e.g. Daphnidae) because they occupy the same food niche (Bogdan and Gilbert, 1984, 1987; Brendelberger, 1985; Brendelberger and Geller, 1985; Gilbert, 1985; Infante and Edmondson, 1985; Kerfoot et al., 1985; Knisely and Geller, 1986) but they can easily coexist with small Cladocerans such as Bosminidae (Gilbert, 1988). According to the Saprobic system, the Rotifers Keratella quadarata, Brachionus spp., Polyarthra euryptera, Asplanchna priodonta and Filinia longiseta are classified as oligo- $\beta$-mesosaprobic or $\beta$-mesosaprobic and they are typical of meso-eutrophic waters (Sládeček, 1983). Another indicator of a meso-eutrophic level is the Cladoceran Bosmina longirostris: it is still the most abundant species 24 years later, but its density has decreased from nearly 500,000 ind $\mathrm{m}^{-3}$ to a maximum density of 2000 ind $\mathrm{m}^{-3}$.

Chemical parameters do not show detrimental changes between the past and today: for example, nitrogen compounds recorded in 2011-2012 are lower than they were in the past. However, all chemical parameters classify TO oxbow lake as a mesotrophic basin.
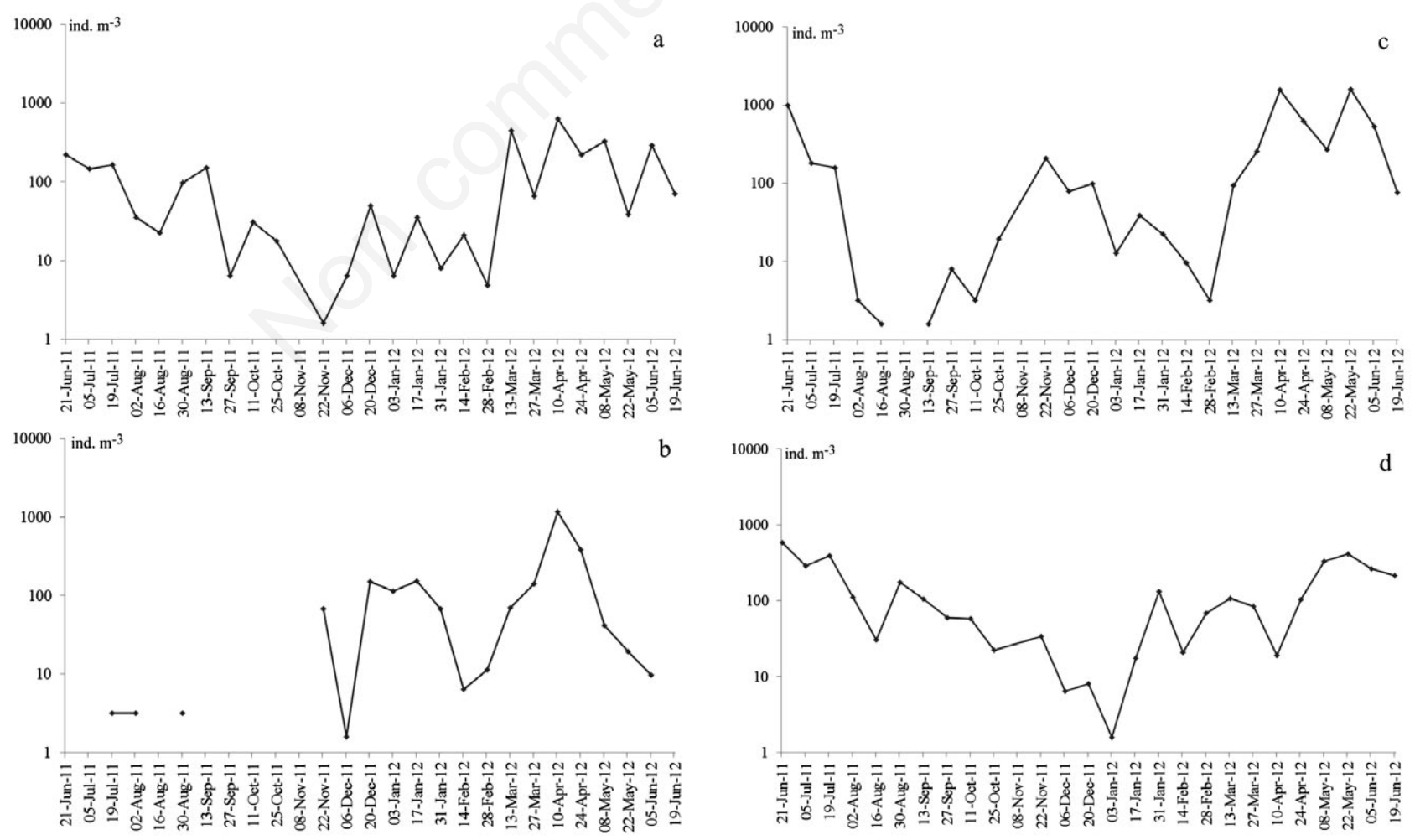

Fig. 7. Seasonal trend (logarithmic scale) of the dominant species of the zooplankton community (ind. $\mathrm{m}^{-3}$ ). a) Asplanchna priodonta; b) Keratella quadrata; c) Bosmina longirostris; d) nauplii. 


\section{CONCLUSIONS}

The geo-morphological and biotic community changes in the TO oxbow lake are typical of riverine wetlands, thus supporting the hypothesis that TO is following its natural evolution. According to data recorded by the Agenzia Regionale per la Protezione Ambientale (ARPA), 1988-1990 were years with lower rainfall (500 mL/year) than those registered in 2011-2012 (900 mL/year) but, despite that, the water area of the oxbow lake has reduced. The decreasing hydrometric level of the Ticino river, and consequently of the perched aquifer that feeds the oxbow lake, has probably accelerated the evolution of the wetland towards progressive impoundment. The high plant biomass that existed in the past could be considered to have been the first step towards eutrophication, but the oxbow lake remained at mesotrophic level due to high biodiversity and dissolved oxygen levels in the water (Sconfietti and Airò, 1992).

Nowadays, the lower aquatic plant biodiversity (Tab. 2) suggests a trophic level shift towards eutrophication. By following the zooplankton community, we can reach the same conclusion: a loss of biodiversity and a reduction in the density of zooplankters could be due to the endogenous evolution of the oxbow lake. These ideas are not supported by physical and chemical parameters which suggest that TO is still at mesotrophic level. The high abundance of aquatic plants directly reduces the levels of dissolved nitrogen compounds, which are the principal source of available nitrogen for primary production, by segregating them within plant tissue; this may explain why we classify the oxbow lake as a mesotrophic basin. However, assessing the trophic level of an oxbow lake through chemical parameter boundaries found in literature is problematic because the values usually refer to lakes, as reported in Margalef (1983). The zooplankton community is certainly a useful indicator of trophic conditions of the water, but its changes are also linked to other ecological factors such as fish predation and water pollution and it is thus difficult to determine which is the main factor; changes in species composition is also due to a natural evolution of the community, as reported by Ferrara et al. (2002) for lake Bracciano, and Tavernini et al. (2009) in the northern Appennini. Nevertheless, as suggested by Cottenie et al. (2003), other environmental variables that have not been measured may affect the zooplankton community structure.

Our results suggest that this oxbow lake is an important habitat from an ecological point of view because it is one of the few riverine biotopes where the anthropogenic pressure is not as high as in other wetlands. The biodiversity loss is mainly due to the natural evolution of the marshy ecosystem, characterised by a progressive and low impoundment, so it should not be considered as an environmental alarm. River erosion activity, deposition and flood events are part of a complex dynamic geomorphological process which leads to new lentic biotopes and wetlands.
However, anthropogenic rectification of a river alters this virtuous mechanism, often disrupting the formation of new wetlands; as a consequence, the disappearance of a wetland is not compensated for by the creation of a new one.

Therefore, despite its loss of biodiversity, the TO oxbow lake still contributes to maintaining high environmental variability in an area surrounded by intensive agricultural activities such as the Ticino river plain. This is one of the main reasons why a gentle restoration of this biotope is planned within the Cariplo Foundation project Ecological and hydromorphological requalification of wetlands in the Ticino area around Pavia: a slight excavation of the bottom of the oxbow lake and a restoration of the original hydraulic interconnection between TO oxbow lake and other adjacent wetlands, with the aim of rejuvenating the physical habitat to ensure the long-term ecological functioning of the aquatic environment. Furthermore, preceded by the eradication of some specimens of Nuphar lutea, it would be beneficial to attempt to reintroduce the threatened aquatic species Nymphaea alba, which was very abundant 24 years ago.

\section{ACKNOWLEDGMENTS}

This study is part of the Cariplo Foundation project Ecological and hydromorphological requalification of wetlands in the Ticino area around Pavia.

We would like to thank Prof. Italo Venzaghi for his support in the interpretation of chemical data and we gratefully thank Charlotte Buckmaster for revising the English text.

\section{REFERENCES}

Blindow I, 1992. Decline of charophytes during eutrophication: comparison with angiosperms. Freshwater Biol. 28:9-14.

Blindow I, 1994. [Rare and threatened charophytes in Sweden]. [Article in Swedish]. Svensk. Bot. Tidskr. 88:65-73.

Bogdan KG, Gilbert JJ, 1984. Body size and food size in freshwater zooplankton. P. Natl. Acad. Sci. 82:6427-6431.

Bogdan KG, Gilbert JJ, 1987. Quantitative comparison of food niches in some freshwater zooplankton: a multi-tracer-cell approach. Oecologia 72:331-340.

Brendelberger H, 1985. Filter mesh-size and retention efficiency for small particles: comparative studies with Cladocera. Arch. Hydrobiol. Beih. Ergebn. Limnol. 21:135-146.

Brendelberger H, Geller W, 1985. Variability of filter structures in eight Daphnia species: mesh sizes and filtering areas. J. Plankton Res. 7:473-486.

Cantonati M, Sconfietti R, 1996. Short term evolution of the zooplankton community in a lateral fluvial ecosystem, $p$. 131-144. In: J. Cruz-Sanjuliàn and J. Benavente (eds.), Wetlands: a multiapproach perspective. Water Research Institute, University of Granada ed.

Carbiener R, Trémoliéres M, Mercier JL, Ortscheit A, 1990. Aquatic macrophyte communities as bioindicators of eutrophication in calcareous oligosaprobe stream waters (Upper Rhine plain, Alsace). Vegetatio 86:71-88. 
Clarke KR, Warwick RM, 1994. Change in marine communities: an approach to statistical analysis and interpretation. Plymouth Marine Laboratory, Plymouth: 144 pp.

Corillion R, 1975. [Flore et végétation du massif armoricain. IV. Flore des Charophytes (Characées) du massif armoricain et des contre'es voisines d'Europe occidentale]. [Book in French]. Jouve Publ., Paris: 214 pp.

Cottenie K, Michels E, Nuytten N, de MeesterSource L, 2003. Zooplankton metacommunity structure: regional vs. local processes in highly interconnected ponds. Ecology 84:9911000 .

Ellenberg H, 1974. [Zeigerwerte der Gefässpflanzen Mitteleuropas]. [Book in German]. Goltze, Göttingen: 122 pp.

European Community, 1992. Council directive of 21 May 1992 on the conservation of natural habitats and of wild fauna and flora, 92/43/EEC. In: Official Journal, L206, 22/07/1992.

European Community, 2000. Council directive of the European Parliament and of the Council of 23 October 2000 establishing a framework for Community action in the field of water policy, 2000/60/EC. In: Official Journal, L327/1, 23/10/2000.

Ferrara O, Vagaggini D, Margaritora FG, 2002. Zooplankton abundance and diversity in Lake Bracciano, Latium, Italy. J. Limnol. 61:169-175.

Gilbert JJ, 1985. Competition between rotifers and Daphnia. Ecology 66:1943-1950.

Gilbert JJ, 1988. Suppression of Rotifer populations by Daphnia: a review of the evidence, the mechanisms, and the effects on zooplankton community structure. Limnol. Oceanogr. 33:1286-1303.

Gomarasca S, Beghi A, Castiglioni A, Bonomi F, Roella V, 2010. Studies about macrophytes of the Varese province lakes (Lombardy, Northern Italy), p. 205-214. In: R. Bolpagni and A. Oggioni (eds), [Macrofite e ambiente]. [Book in Italian]. Eurac Research ed.

Grosse W, 1996. Pressurized ventilation in floating-leaved aquatic macrophytes. Aquat. Bot. 54:137-150.

Hutchinson GE, 1975. A treatise on limnology. 3. John Wiley \& Sons, New York: 660 pp.

Infante A, Edmondoson WT, 1985. Edible phytoplankton and herbivorous zooplankton in Lake Washington. Arch. Hydrobiol. Beih. Ergebn. Limnol. 21:161-171.

Kerfoot WC, DeMott WR, DeAngelis DL, 1985. Interactions among Cladocerans: food limitation and exploitative competition. Arch. Hydrobiol. Beih. Ergebn. Limnol. 21:431-451.

Knisely K, Geller W, 1986. Selective feeding of four zooplankton species on natural lake phytoplankton. Oecologia 69:86-94.

Margalef R, 1983. [Limnologia]. [Book in Spanish]. Omega ed., Barcellona: 1009 pp.

Margaritora FG, Ferrara O, Vagaggini D, 2001. Predatory impact of the mosquitofish (Gambusia holbrooki Girard) on zooplanktonic populations in a pond at Tenuta di Castelporziano (Rome, Central Italy). J. Limnol. 60:189-193.

Moss B, Kornijow R, Measey GJ, 1998. The effects of nimphaeid (Nuphar lutea) density and predation by perch (Perca fluviatilis) on the zooplankton communities in a shallow lake. Freshwater Biol. 39:689-697.

Laing HE, 1941. Effect of concentration of oxygen and pressure of water upon growth of rhizomes of semi-submerged water plants. Bot. Gaz. 102:712-724.

Pignatti S, 1980. Reflections on the phytosociological approach and the epistemological basis of vegetation science. Vegetatio 42:181-185.

Ramsar, 1971. Convention on Wetlands of International Importance especially as Waterfowl Habitat. Ramsar (Iran), 2 February 1971. UN Treaty Series No. 14583. As amended by the Paris Protocol, 3 December 1982, and Regina Amendments, 28 May 1987. Available from: http:/www.ramsar. org/cda/en/ramsar-documents-texts-convention-on/main/ ramsar/1-31-38^20671_4000_0

Regione Lombardia, 2010. [Flora e piccola fauna protette in Lombardia]. [Book in Italian]. Centro Flora Autoctona della Regione Lombardia ed., Oggiono: 351 pp.

Sacchi CF, Occhipinti Ambrogi A, Sconfietti R, 1991. [Gli ecosistemi stagnali pavesi: problemi e prospettive]. [Article in Italian]. S.IT.E Atti 12:469-475.

Sacchi CF, Sconfietti R, Occhipinti A, 1993. [Ambienti fluviali marginali: lanche del pavese]. [Article in Italian]. Acqua Aria 7:738-741.

Sconfietti R, 1993. [Note ecologiche sulla comparsa della medusa Craspedacusta sowerbyi Lankester, 1880 in una lanca di Ticino (Hydrozoa, Limnomedusae)]. [Article in Italian]. Boll. Mus. Civ. St. nat. Verona 17:201-212.

Sconfietti R, Airò S, 1992. [Ritmi nictemerali in ambienti lentici padani a diverso grado di trofia]. [Proceedings in Italian]. In: Proc. $10^{\text {th }}$ Gadio Congress, pp. 403-412.

Sconfietti R, Airò S, Cantonati M, Cattani S, Rossini P, 1990. [Ricerche sul trofismo di ecosistemi stagnali lombardi: cicli stagionali e nictemerali in una lanca del Ticino]. [Proceedings in Italian]. In: Proc. $10^{\text {th }}$ Gadio Congress, pp. 283-308.

Sconfietti R, Cantonati M, 1990. A zooplankton net for very shallow waters. Riv. Idrobiol. 29:669-674.

Sconfietti R, Cariboni M, Cantonati M, 1992. [Ricerche sulla ciclo morfosi del Cladocero Bosmina longirostris (O.F. Müller)]. [Proceedings in Italian]. In: Proc. $10^{\text {th }}$ Gadio Congress, pp. 477-486.

Sconfietti R, Paganelli D, 2012. [IMPaL: proposta di un metodo di rapid assessment per la definizione della qualità paesaggistica delle lanche fluviali]. [Article in Italian]. Biologia Ambientale 26:23-31.

Schmitz OJ, 2012. Restoration of ailing wetlands. PLoS Biology 10:e1001248.

Shannon CE, Weaver W, 1949. The mathematical theory of communication. University of Illinois ed., Urbana and Champaign: $177 \mathrm{pp}$.

Shimoda M, 1993. Habitats of the genus Nuphar Sm. in the Saijo basin, Hiroshima prefecture, western Japan. J. Phytogeogr. Taxon. 41:107-111.

Sládeček V, 1983. Rotifers as indicators of water quality. Hydrobiologia 100:169-201.

Smits AJM, De Lyon MJH, Van Der Velde G, Steentjes PLM, Roelofs JGM, 1988. Distribution of three nymphaeid macrophytes [Nymphaea alba L., Nuphar lutea (L.) Sm., and Nymphoides peltata (Gmel.) O. Kuntze] in relation to alkalinity and uptake of inorganic carbon. Aquat. Bot. 32:45-62.

Stemberger RS, Gilbert JJ, 1985. Body size, food concentration, and population growth in plank- tonic rotifers. Ecology 66:1151-1159.

Tavernini S, Primicerio R, Rossetti G, 2009. Zooplankton assembly in mountain lentic waters is primarily driven by local processes. Acta Oecol. 35:22-31. 